Article

LANZA, T.R. ${ }^{1 *}$

MACHADO, A.F.L. ${ }^{1}$

MARTELLETO, L.A.P. ${ }^{1}$

\section{Effect of Planting Densities of "BRS Princess" Banana Tree in The SuPPREssion OF WeEdS}

\author{
Efeito de Densidades de Plantio da Bananeira BRS Princesa na Supressão de \\ Plantas Daninhas
}

\begin{abstract}
The objective is to evaluate the effects of plant density in banana crops against weed suppression. Six treatments were used: $1,200(3.33 \times 2.5 \mathrm{~m}), 1,600$ $(2.5 \times 2.5 \mathrm{~m}), 2,000(2.0 \times 2.5 \mathrm{~m}), 2,400(1.67 \times 2.5 \mathrm{~m}), 2,800(1.43 \times 2.5 \mathrm{~m})$ and 3,200 $(1.25 \times 2.5 \mathrm{~m})$ banana plants per hectare, arranged in an experimental design of randomized blocks with four replications. The phytosociological study of weed communities was carried out one month after transplanting and then every 90 days, totaling six samples in 16 months of cultivation, always those being held 15 days after mowing. With the data of dry mass and number of individuals per species Relative density (De.R) Relative frequency (Fr.R) Relative dominance (Do.R), importance value value (IVI) of weed communities were calculated. Forty-three 43 species of weeds associated with the crop were identified, especially in the early stages of culture, of species such as Panicum maximum and nut grass. After 90 DAT it was found that the increase in the diversity of weed species, besides the reduction in IVI of P. maximum and C. rotundus, and increased IVI for species such as C. benghalensis and Vernonia cinerea, were more adapted to shade conditions. There was a reduction in the density dominance of weeds in higher plant density treatments, especially between 210 and 300 DAT. There was a change in the population of weeds, depending on the plant spacings in the banana crop.
\end{abstract}

Keywords: banana crop, phytosociology, crop management.

RESUMO - Objetivou-se neste trabalho avaliar o efeito do adensamento de plantas na cultura da banana em relação à supressão de plantas daninhas. Utilizaram-se seis tratamentos: $1.200(3,33 \times 2,5 \mathrm{~m}), 1.600(2,5 \times 2,5 \mathrm{~m}), 2.000(2,0 \times 2,5 \mathrm{~m}), 2.400$ $(1,67 \times 2,5 \mathrm{~m}), 2.800(1,43 \times 2,5 \mathrm{~m})$ e $3.200(1,25 \times 2,5 \mathrm{~m})$ plantas de bananeira por hectare, dispostas em delineamento experimental de blocos ao acaso com quatro repetições. $O$ estudo fitossociológico da comunidade de plantas daninhas foi realizado após um mês do transplantio e, posteriormente, a cada 90 dias, totalizando seis amostragens em 16 meses de cultivo. Com os dados de massa seca e número de indivíduos por espécie, calculou-se: densidade relativa (De.R), frequência relativa (Fr.R), dominância relativa (Do.R) e, índice do valor de importância (IVI) da comunidade de plantas daninhas. Foram identificadas 43 espécies de plantas daninhas associadas à cultura, com predominância nas fases iniciais da cultura, de espécies como Panicum maximum e Cyperus rotundus. Após 90 DAT, constatou-se o aumento na diversidade de espécies de plantas daninhas, além da redução no IVI de P. maximum e $\boldsymbol{C}$. rotundus, e aumento de IVI para espécies como Commelina benghalensis e Vernonia cinerea, mais adaptadas a condições de sombreamento. Houve redução na densidade e dominância das

Planta Daninha 2017; v35:e017162958

1 Universidade Federal Rural do Rio de Janeiro, Seropédica, Rio de Janeiro, RJ, Brasil.

.


plantas daninhas nos tratamentos de maior densidade de plantio, principalmente entre 210 e 300 DAT. Verificou-se alteração da população de plantas daninhas em função dos espaçamentos de plantas na cultura da banana.

Palavras-chave: bananicultura, fitossociologia, manejo cultural.

\section{INTRODUCTION}

Among fruit trees, banana is the world's leading producer of 107 million tons (FAO, 2015). Brazil is the fifth world producer of bananas, having produced approximately 7.3 million tons in 2014, in an approximate area of 503 thousand hectares, with a yield value of BRL 4.37 billion (FAO, 2015; IBGE, 2015).

One of the critical points in the banana production process is weed interference. They compete with the crop for water, light, nutrients and carbon dioxide. They can also release allelopathic substances that can influence crop development, as well as host pests and diseases. Therefore, an adequate management of weeds is of critical importance to obtain productivity in banana crops (Moura Filho et al., 2015).

The first five months after banana planting are the most limiting for the crop. At this stage, weed control must be adequately carried out so that banana trees growth is not affected. After this period, the crop shades the area and becomes less sensitive to competition with weeds (Costa, 2007). This shading leads to changes in the microclimate, disfavoring some weeds, especially those of type $\mathrm{C} 4$ metabolism, which require a high index of luminosity.

Several weeds develop in association with banana such as Benghal dayflower (Commelina benghalensis), densetuft hairsedge (Cyperus sp.), fameflower (Talinum paniculatum), crabgrass (Digitaria horizontalis), mile-a-minute vine (Ipomoea cairica), and Florida tasselflower (Emilia fosbergii). These species present good ability to adapt to the conditions resulting from the presence of the crop, such as shading and humidity, causing significant reductions in yield, which requires an adequate management (Alves, 2005; Gomes et al., 2010; Lima et al., 2012; Moura Filho et al., 2015).

The first stage for the proper management of weeds in crops involves the identification of the weed species present in the area, as well as those that are of greater importance. For this, phytosociological parameters of the weed community, such as frequency, density and dominance, are taken into account. After this phase, it is possible to decide the best management to be adopted (Oliveira and Freitas, 2008). Thus, phytosociological studies compare weed populations at a given time and may indicate trends of variation of the importance of one or more populations in relation to the time and/or even the agricultural practices adopted.

Thus, in relation to weed management, crop control can demonstrate an efficient strategy with lower implementation costs. Row spacing and planting density of crops may influence their ability to compete with weeds for resources and therefore they may affect their management (Grichar et al., 2004; Isaac et al., 2007).

In this sense, the objective of this work was to evaluate the plant densification effect of the Maçã BRS Princesa (silk) banana type on weed suppression and dynamics.

\section{MATERIAL AND METHODS}

The study was carried out in the Brazilian municipality of Seropédica, RJ $\left(22^{\circ} 45^{\prime} 08.62\right.$ " S and $43^{\circ} 40^{\prime} 28.50^{\prime \prime} \mathrm{W}$ ), at an altitude of $27 \mathrm{~m}$, where the Köppen Aw climate classification type predominates, with wet summers and dry winters. The average annual temperature is about $24.5{ }^{\circ} \mathrm{C}$ and the average precipitation is $1,200 \mathrm{~mm}$ (INMET, 2015). The soil of the experimental area is classified as Acrisol, with sandy loam and clayey loam granulometric characteristics.

BRS Princesa banana (Musa sp.) seedlings were used and the area was implemented in August 2014. Treatments consisted of planting densities, being 1,200 (3.33 x $2.5 \mathrm{~m}), 1,600$ ( $2.5 \times 2.5 \mathrm{~m}), 2,000(2.0 \times 2.5 \mathrm{~m}), 2,400(1.67 \times 2.5 \mathrm{~m}), 2,800(1.43 \times 2.5 \mathrm{~m})$ and $3,200(1.25 \times 2.5 \mathrm{~m})$ 
plants per hectare, arranged in the experimental design of randomized blocks with four replications. The experimental unit consisted of 12 banana plants (three rows of four plants) and the three plants of the central row were considered the useful plants. A conventional preparation of the soil was adopted, with plowing, harrowing and ploughing of the rows. The conduction of the experiment was carried out according to the recommendations for the crop (Borges et al., 2004), topdressing, shoot elimination and clearing of tussocks, especially the removal of dead and dry leaves every 15 days.

Soil samples were collected at depths of $0-20$ and $20-40 \mathrm{~cm}$ in pre-planting in the experiment area and submitted to (granulometric) chemical and physical analyses. The results are shown in Table 1.

Table 1 - Results of chemical and granulometric analyses of the soil of the experimental area - Seropédica, RJ

\begin{tabular}{|c|c|c|c|c|c|c|c|c|c|c|c|c|c|c|c|}
\hline \multirow{2}{*}{$\begin{array}{l}\text { Prof. } \\
\text { (cm) }\end{array}$} & $\mathrm{Na}$ & $\mathrm{Ca}$ & $\mathrm{Mg}$ & $\mathrm{K}$ & $\mathrm{H}+\mathrm{Al}$ & $\mathrm{Al}$ & $\mathrm{S}$ & $\mathrm{T}$ & $\mathrm{V}$ & $\mathrm{m}$ & $\mathrm{n}$ & \multirow{2}{*}{$\begin{array}{c}\text { water } \mathrm{pH} \\
(01: 02.5)\end{array}$} & Corg & $\mathrm{P}$ & $\mathrm{K}$ \\
\hline & \multicolumn{8}{|c|}{$\left(\mathrm{cmol}_{\mathrm{c}} \mathrm{dm}^{-3}\right)$} & \multicolumn{3}{|c|}{$(\%)$} & & $(\%)$ & \multicolumn{2}{|c|}{$\left(\mathrm{mg} \mathrm{dm}^{-3}\right)$} \\
\hline $0-20$ & 0.05 & 3.9 & 2.7 & 0.27 & 1.3 & 0 & 6.92 & 8.22 & 84 & 0 & 1 & 6.2 & 2.78 & 4 & 106 \\
\hline $20-40$ & 0.054 & 3.7 & 1.4 & 0.11 & 2 & 0 & 5.26 & 7.26 & 72 & 0 & 1 & 6 & 1.13 & 1 & 42 \\
\hline \multicolumn{16}{|c|}{$\mathrm{m}$ (sat. per Al); $\mathrm{n}$ (sat. per Na); - Extractors: $\mathrm{KCl}$, Mehlich and Calcium Acetate } \\
\hline \multirow{2}{*}{$\begin{array}{l}\text { Prof. } \\
(\mathrm{cm})\end{array}$} & $\begin{array}{l}\text { Clay } \\
\text { Nat }\end{array}$ & & $\begin{array}{l}\text { Clay } \\
\text { Total }\end{array}$ & $\begin{array}{l}\text { San } \\
\text { Tot }\end{array}$ & & $\begin{array}{l}\text { oarse } \\
\text { sand . }\end{array}$ & & & Silt & & $\begin{array}{l}\text { Gral } \\
\text { Floc }\end{array}$ & \multirow{2}{*}{\multicolumn{2}{|c|}{$\begin{array}{l}\text { Detailed } \\
\text { SBCS* }\end{array}$}} & \multirow{2}{*}{\multicolumn{2}{|c|}{$\begin{array}{l}\text { Simplified } \\
\text { SBCS* }\end{array}$}} \\
\hline & \multicolumn{11}{|c|}{$(\%)$} & & & & \\
\hline $0-20$ & 12 & & 18 & 72 & & 43 & & & 10 & & 36 & \multicolumn{2}{|c|}{ Loam clayey } & \multicolumn{2}{|c|}{ Mean } \\
\hline $20-40$ & 12 & & 22 & 70 & & 50 & & & 8 & & 45 & \multicolumn{2}{|c|}{ Loam clayey } & \multicolumn{2}{|c|}{ Mean } \\
\hline
\end{tabular}

* Sociedade Brasileira de Ciência do Solo (Brazilian Society of Soil Science).

Phytosociological evaluations were carried out in the agricultural year of 2014/15, with the first evaluation taking place 30 days after the preparation of the area (time zero), and the other five at every 90 days. Weed management, whenever necessary, was done by mowing, and weed collections, when performed, would be after 15 days of mowing in order to standardize the management effect. In each experimental plot, three samplings were established by means of randomly launching a metal square measuring $0.30 \mathrm{~m}$ on the sides. At each launch, the weeds shoots inside the square were harvested and the individuals were counted and identified by family, genus and species. The samples were then placed in an oven with forced air ventilation at $60{ }^{\circ} \mathrm{C}$ for 72 hours until reaching a constant mass. Subsequently, the samples were weighed on a precision scale to quantify the dry matter.

With the data obtained, the phytosociological indexes were calculated: relative density (De.R), relative frequency (Fr.R) and relative dominance (Do.R), which are used to calculate the Importance Value Index (IVI), according to methodology proposed by Müeller-Dombois and Ellemberg (1974) and described by Pitelli (2000) in:

- De.R $=($ species density/species total density) $\times 100$

- Fr.R $=$ (species frequency/species total frequency) $x 100$

- Do.R $=$ (species dry matter/species total dry matter) $\times 100$

- IVI $=$ De.R + Fr.R + Do.R

Data on the effect of banana densification on weed average dominance and density were submitted to analysis of variance and linear regression models were adjusted to $5 \%$ probability.

\section{RESULTS AND DISCUSSION}

During the 16 months of banana cultivation, it was possible to identify the occurrence of 43 weed species distributed in 15 families and 37 genera (Table 2). The predominance of species of the families Poaceae, Asteraceae and Malvaceae is highlighted, which together represent 
Table 2 - Scientific name, common name, family and class of weed species collected and identified during the evaluation period of the experiment Seropédica, RJ

\begin{tabular}{|c|c|c|c|}
\hline Scientific name & Common name & Family & Class \\
\hline Amaranthus deflexus & Large-fruit amaranth, low amaranth, and Argentina amaranth & Amaranthaceae & Dicotyledonous \\
\hline Acanthospermum hispidum & Bristly starbur, goat's head, hispid starburr, or starbur & Asteraceae & Dicotyledonous \\
\hline Ageratum conyzoides & Billygoat-weed, chick weed, goatweed, whiteweed & Asteraceae & Dicotyledonous \\
\hline Bidens pilosa & Black-jack, beggarticks, cobbler's pegs, or Spanish needle & Asteraceae & Dicotyledonous \\
\hline Blainvillea biaristata & Erva-palha & Asteraceae & Dicotyledonous \\
\hline Conyza bonariensis & Flax-leaf Fleabane, Wavy-leaf Fleabane and Argentine Fleabane & Asteraceae & Dicotyledonous \\
\hline Emilia coccinea & Scarlet tasselflower & Asteraceae & Dicotyledonous \\
\hline Emilia fosbergii & Florida tasselflower & Asteraceae & Dicotyledonous \\
\hline Galinsoga parviflora & Gallant soldier & Asteraceae & Dicotyledonous \\
\hline Vernonia cinerea & Dandotapala & Asteraceae & Dicotyledonous \\
\hline Cleome sp. & Spider flowers, spider plants, spider weeds, or bee plants & Brassicaceae & Dicotyledonous \\
\hline Commelina benghalensis & Benghal dayflower & Commelinaceae & Monocotyledonous \\
\hline Ipomoea ramosissima & Heart-leaved morning glory & Convolvulaceae & Dicotyledonous \\
\hline Merremia cissoides & Littlebell and Aiea morning glory & Convolvulaceae & Dicotyledonous \\
\hline Cyperus rotundus & $\begin{array}{l}\text { Coco-grass, Java grass, nut grass, purple nut sedge or purple nutsedge, red nut sedge, Khmer } \\
\text { kravanh chruk }\end{array}$ & Cyperaceae & Monocotyledonous \\
\hline Acalypha communis & Copperleaf & Euphorbiaceae & Dicotyledonous \\
\hline Chamaesyce hirta & Asthma-plant & Euphorbiaceae & Dicotyledonous \\
\hline Chamaesyce hyssopifolia & Hyssopleaf sandmat & Euphorbiaceae & Dicotyledonous \\
\hline Euphorbia heterophylla & $\begin{array}{l}\text { (Mexican) fireplant, painted euphorbia, Japanese poinsettia, desert poinsettia, wild poinsettia, } \\
\text { fire on the mountain, paintedleaf, painted spurge, milkweed, and kaliko plant }\end{array}$ & Euphorbiaceae & Dicotyledonous \\
\hline Alysicarpus ovalifolius & Alyce clover, false moneywort & Fabaceae & Dicotyledonous \\
\hline Calopogonium mucunoides & Calapo, calopo, wild ground nut & Fabaceae & Dicotyledonous \\
\hline Indigofera hirsuta & Hairy indigo, rough hairy indigo & Fabaceae & Dicotyledonous \\
\hline Sida acuta & $\begin{array}{l}\text { Arrowleaf sida, Paddy's lucerne, jelly leaf, and also somewhat confusingly as Cuban jute, } \\
\text { Queensland hemp, and Indian hemp }\end{array}$ & Malvaceae & Dicotyledonous \\
\hline Sida spinosa & Prickly fanpetals & Malvaceae & Dicotyledonous \\
\hline Sida urens & Shrubby false buttonweed & Malvaceae & Dicotyledonous \\
\hline Waltheria sp. & $\begin{array}{l}\text { Sleepy morning, basora prieta, hierba de soldado, guimauve, mauve-gris, moto-branco, } \\
\text { fulutafu, kafaki, and 'uhaloa (Hawaii) }\end{array}$ & Malvaceae & Dicotyledonous \\
\hline Oxalis latifolia & Garden pink-sorrel or broadleaf woodsorrel & Oxalidaceae & Dicotyledonous \\
\hline Phyllanthus niruri & Leafflower & Phyllanthaceae & Dicotyledonous \\
\hline Phyllanthus tenellus & Mascarene Island leaf-flower & Phyllanthaceae & Dicotyledonous \\
\hline Cynodon dactylon & $\begin{array}{l}\text { Vilfa stellata dūrvā grass, Dhoob, Bermuda grass, dubo, dog's tooth grass, Bahama grass, } \\
\text { devil's grass, couch grass, Indian doab, arugampul, grama, wiregrass and scutch grass }\end{array}$ & Poaceae & Monocotyledonous \\
\hline Digitaria horizontalis & Jamaican crabgrass & Poaceae & Monocotyledonous \\
\hline Eleuzine indica & Indian goosegrass, yard-grass, goosegrass, wiregrass, or crowfootgrass & Poaceae & Monocotyledonous \\
\hline Eragrostis airoides & Darnel lovegrass & Poaceae & Monocotyledonous \\
\hline Panicum maximum & Guinea grass, Tanganyika grass, buffalograss & Poaceae & Monocotyledonous \\
\hline Paspalum notatum & Bahiagrass, common bahia, and Pensacola bahia & Poaceae & Monocotyledonous \\
\hline Setaria parviflora & Marsh bristlegrass, knotroot bristle-grass, bristly foxtail and yellow bristlegrass & Poaceae & Monocotyledonous \\
\hline Sporobulus indicus & Smut grass & Poaceae & Monocotyledonous \\
\hline Urochloa sp. & Palisade grass & Poaceae & Monocotyledonous \\
\hline Portulaca oleracea & Purslane, verdolaga, pigweed, little hogweed, red root, pursley & Portulacaceae & Dicotyledonous \\
\hline Talinum triangulare & $\begin{array}{l}\text { Potherb fameflower, waterleaf, Surinam purslane, Ceylon spinach, sweetheart, grassé, poslen, } \\
\text { krokot belanda, talina de Java, espinafre de Ceilao, kumu manus, talilong, galaghati, biala, } \\
\text { som-kaoli, som-khon, som-chin, thoornhaan saam, cariru, lagos bologi }\end{array}$ & Portulacaceae & Dicotyledonous \\
\hline Richardia brasiliensis & Tropical Mexican clover, Brazilian calla-lily, white-eye, and Brazil pusley & Rubiaceae & Dicotyledonous \\
\hline Spermacoce sp. & False buttonweed & Rubiaceae & Dicotyledonous \\
\hline Solanum americanum & American black nightshade, small-flowered nightshade or glossy nightshade & Solanaceae & Dicotyledonous \\
\hline
\end{tabular}

$51 \%$ of the species identified (Figure 1). Among the species cited, 11 belong to the class of monocotyledonous and 32 to the class of dicotyledonous (Table 2).

Regarding the diversity of weed species in relation to time, there was an increase in the number of species up to 300 days after transplanting (DAT). There was also a reduction in the number of species collected in evaluations performed between 300 and 480 DAT (Figure 2). It was noticed that the development of banana trees associated to the use of weed mowing influenced the increase in the diversity of species, probably due to changes in the microclimate below the canopy.

In studies about phytosociological registration carried out by Gomes et al. (2010) in Brazilian city Registro, SP, and Lima et al. (2012) in Brazilian city Bananeiras, PB, 21 and 33 weed species were found respectively, less than in the present study. It should be noted that equal species were found among the studies and it is possible to mention Ageratum conyzoides, Emilia sonchifolia, 


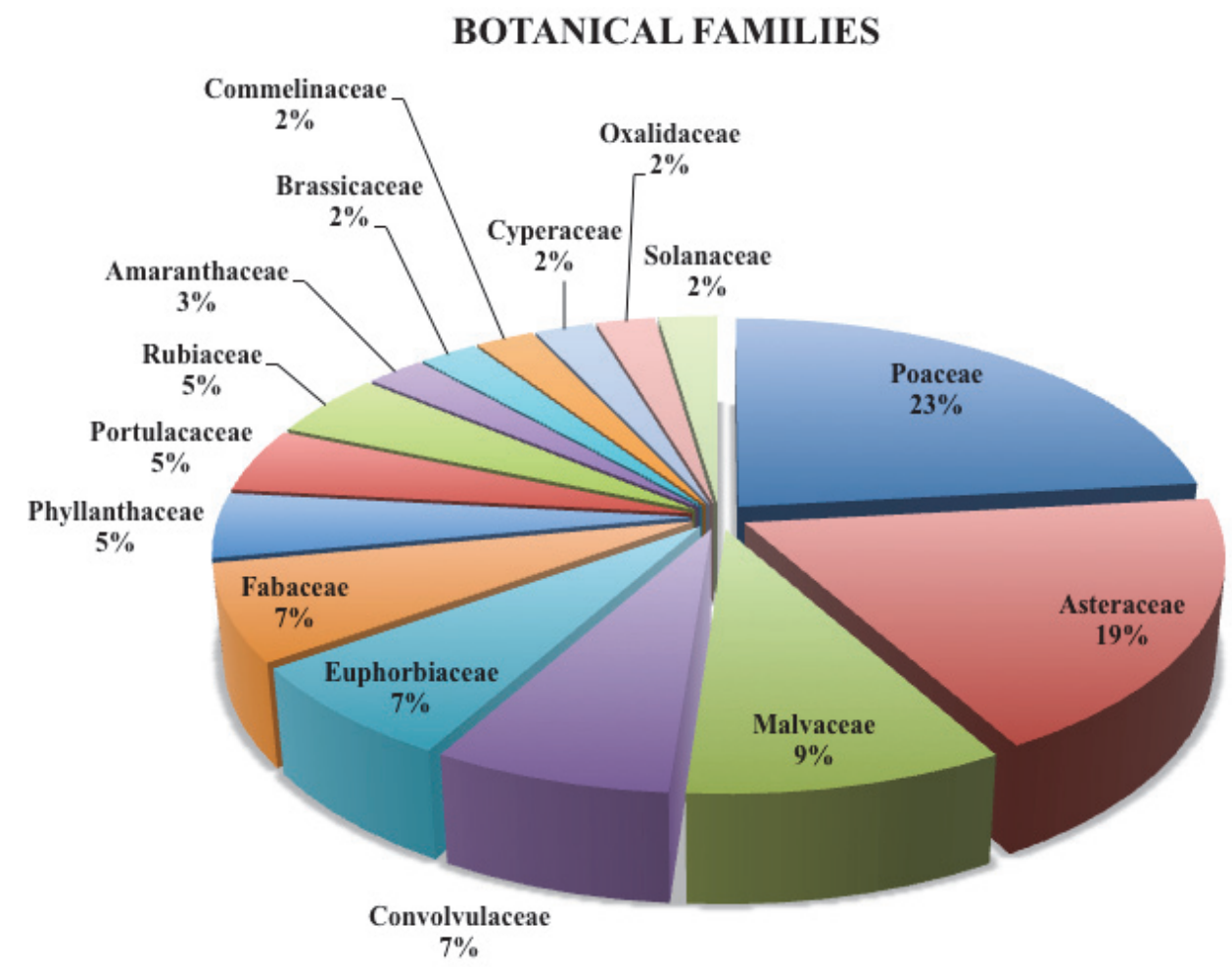

Figure 1 - Botany family and percentage of individuals in each family identified throughout the evaluations - Seropédica, RJ.

Phyllanthus tenellus, Digitaria horizontalis, Panicum maximum, Chamaesyce hirta e Eleusine indica, Emilia fosbergii, Commelina benghalensis, Cyperus rotundus, Cynodon dactylon, Portulaca oleracea, and Richardia brasiliensis.

There are species that had their permanent occurrence in the area, the density varying, such as $C$. rotundus and $C$. benghalensis, identified in all samples taken. Both species presented characteristics that allow them to remain under conditions of low luminosity, as is the case of the treatments of greater population density of banana trees. In addition, they are species with great capacity for vegetative reproduction (Lima et al., 2012), making its control even more difficult.

Also according to Lima et al. (2012), coco-grass (C. rotundus) remains in constant competition with banana trees, being very difficult to eliminate from banana crops. Losses of this species result from competition throughout the cycle but the most critical periods are in the early stages of crop development and crop reform. Because it is a perennial species due to its wide adaptability to many agricultural environments and the ability to reproduce sexually and asexually, it is among the 20 most damaging weed species in the world (Lima et al., 2012).

Sampling results from 30 to 480 DAT indicate changes in weed dynamics and community in all densities of banana plants evaluated. The main characteristic observed was the dominance of a few weed species in the first three months of the culture. These species had high IVI values, predominantly $P$. maximum and $C$. rotundus in all treatments at 30 DAT (Figure 3). In the first collection, 18 weed species were identified, predominantly those with a type $\mathrm{C} 4$ metabolism.

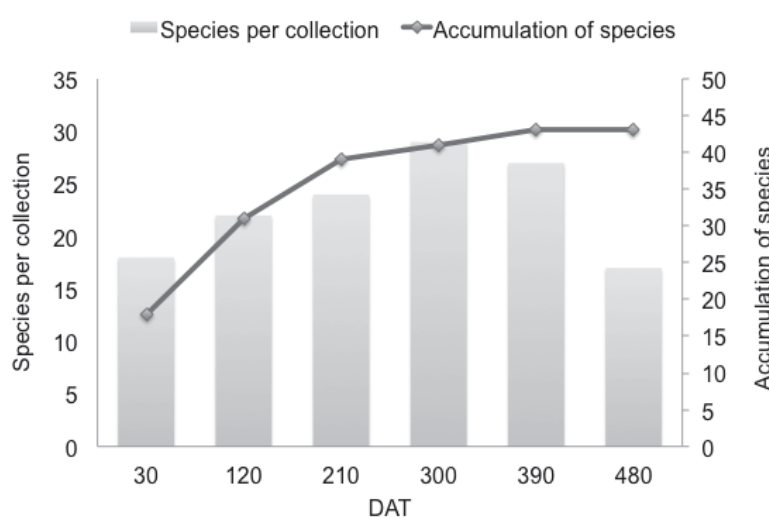

Figure 2 - Species by collection and accumulation of weed species due to time after transplanting (DAT) Seropédica, RJ. 


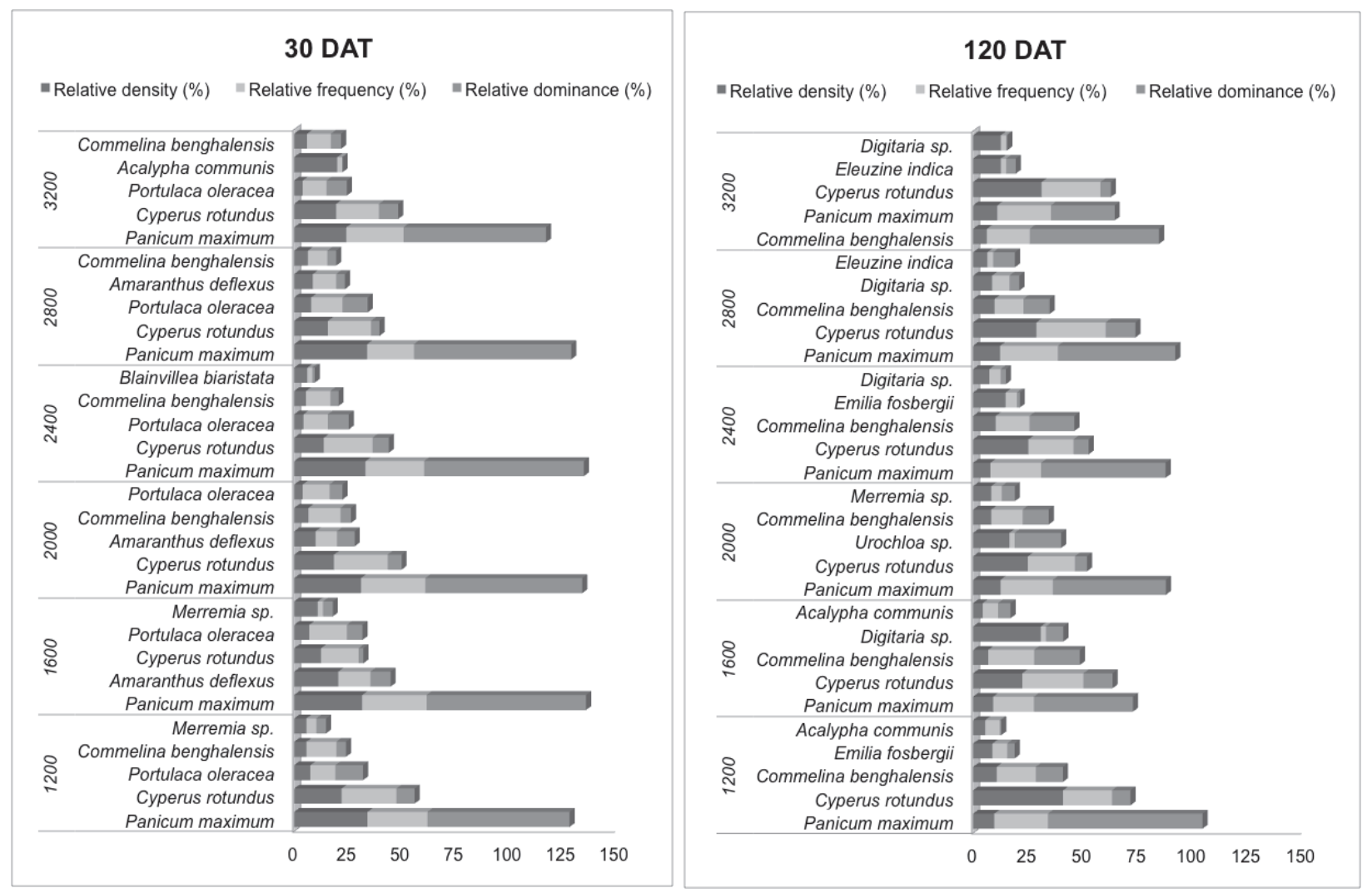

Figure 3 - Relative density (DeR), relative frequency (FrR), relative dominance (DeR) and Importance Value Index $(I V I=$ DeR + FrR + DeR $)$ of the five predominant weed species at 30 and 120 DAT - Seropédica, RJ.

From the 120 DAT it was possible to verify changes in the weed community and diversity, mainly in the increase of IVI for populations such as C. benghalensis and A. communis (Figure 3 ). In this sample 22 weed species were identified and it is possible to notice that $P$. maximum also presents a high IVI but with lower value than $C$. benghalensis in the population density of 3,200 plant ha ${ }^{-1}$ of banana (Figure 3 ). It is observed that this tendency was more pronounced between 210 and 300 DAT, with significant alterations in the composition of species, mainly in the reduction of species $\mathrm{C} 4$ and increase in the diversity and IVI of species C3, such as Emilia coccinea, Commelina benghalensis, Indigofera hirsuta, Alysicarpus oblongifolius, and Acalypha communis, more tolerant to low irradiation.

In the sampling collected at 210 DAT, 24 weed species were identified, being possible to verify the effect of banana plants densification, which begin to shade the area with greater intensity. It is observed that in the treatment of lower population density $\left(1,200\right.$ plant ha $\left.^{-1}\right)$, $P$. maximum still presents the highest IVI value, probably due to the greater incidence of light on the place. As for the treatment of higher population density $\left(3,200\right.$ plant ha $\left.{ }^{-1}\right)$, this same species lost importance compared to others more adapted to this shaded environment, such as C. benghalensis and C. rotundus (Figure 4).

In an evaluation performed at $300 \mathrm{DAT}$, it is observed that the crop control exerted by banana plants on type $\mathrm{C} 4$ weeds becomes even more evident, with a considerable reduction in the overall IVI for all treatments (Figure 4). It is emphasized that species more adapted to this condition of low luminosity, such as C. benghalensis and E. coccinea, remained and even increased IVI at the time of the evaluation at 300 DAT. Species of family Asteraceae, such as E. coccinea and $V$. cinerea, began to predominate in the area and it was possible to attribute these results to the fact that they were Brazilian autumn-winter collections, where naturally there is shorter duration of the day and changes in the weeds occurrence and development (Pitelli et al., 2001).

It was also noticed that at 300 DAT there was a sharp IVI reduction for the species $P$. maximum, which in most of the treatments was not among the five plants with higher IVI (Figure 4). Lower 

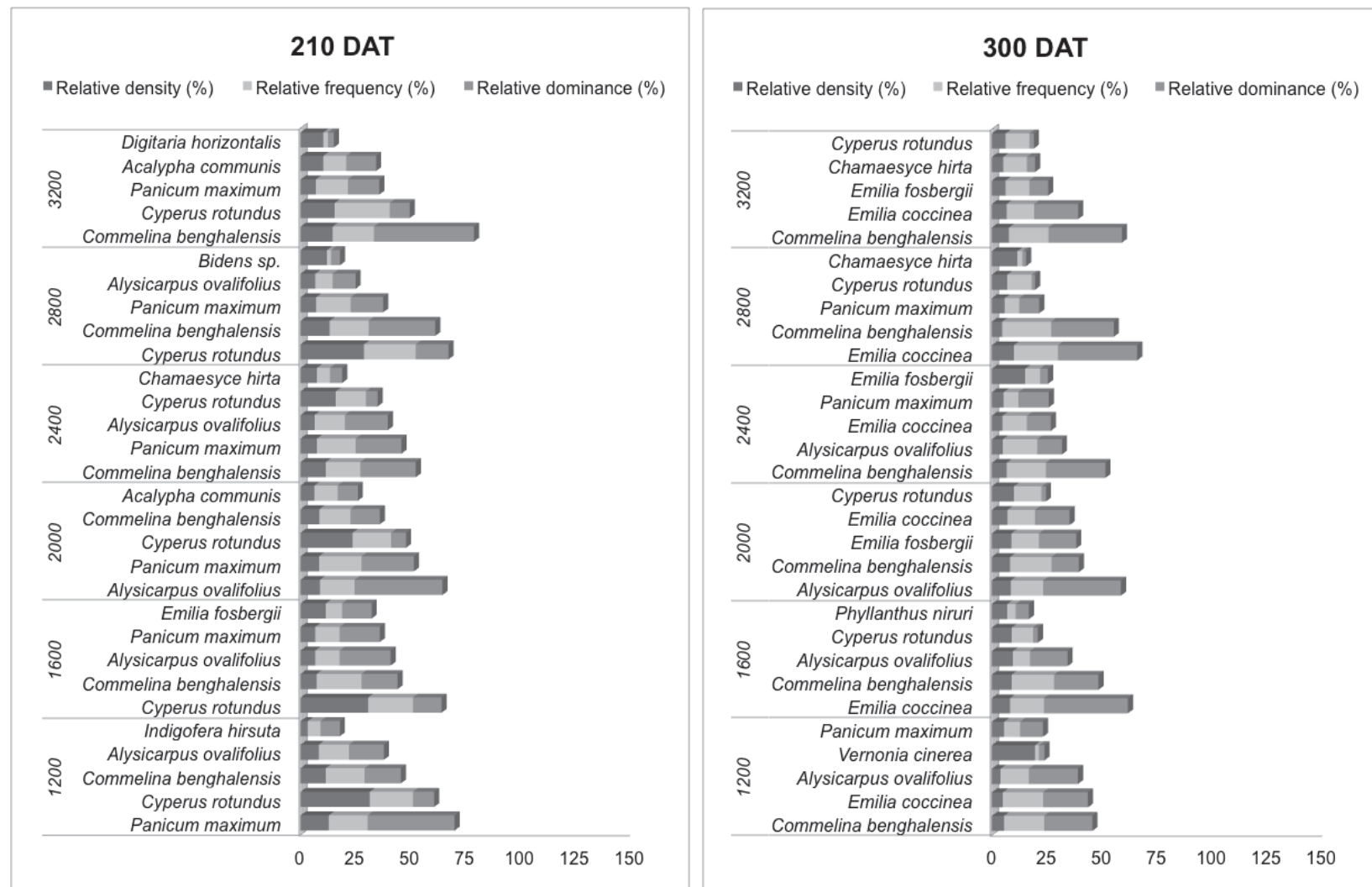

Figure 4 - Relative density (DeR), relative frequency (FrR), relative dominance (DeR) and Importance Value Index $(I V I=$ DeR + FrR + DeR $)$ of the five predominant weed species at 210 and 300 DAT - Seropédica, RJ.

IVI values were found in treatments with higher population density $\left(2,800\right.$ and 3,200 plant ha $\left.^{-1}\right)$ (Figure 4), suggesting that there is more intense shading of the soil, thus reducing the occurrence of weeds.

Weed collection at 390 DAT was done simultaneously with the beginning of crop harvesting, thus allowing a greater input of solar radiation into the system due to the elimination of the aerial part of the harvested plants. The results referring to the 390 and 480 DAT (Figure 5) show a change in the occurrence of weeds, both in the level of soil occupation as in the plant diversity. Type C4 plants such as P. maximum and C. rotundus showed greater development, again occupying the area in places where there was greater light input. In this situation, the IVI of these species was higher than that of the collections prior to the harvest period.

Many species were present at all times of evaluation, such as C. rotundus, which is a fast-growing species, with tubers acting as the main dispersion units over time, remaining dormant in the soil for long periods. Tuber dormancy causes irregular emergence, contributing to the persistence of the propagules of this species in the soil (Machado et al., 2005).

Regarding the effect of treatments on the occurrence of weeds in different collection times, it was verified that there was a correlation between weed reduction and the increase of banana trees plantation density. Weeds dominance and density were influenced by the banana trees growth (Figure 6).

Regarding the weeds dry matter, it was observed that there was also a significant reduction from the 210 DAT but there was no difference after the beginning of the harvest at 390 DAT (Figure 6). For the number of individuals, there was a significant difference between treatments from 210 DAT, thus continuing until harvest (Figure 6). These results are attributed to the higher incidence of solar radiation with the beginning of the harvest, which also coincided with the Brazilian spring-summer period. Therefore, it is verified that the use of higher planting densities favors the cultural control of weeds, thus reducing the need for control between 210 and 300 DAT. 


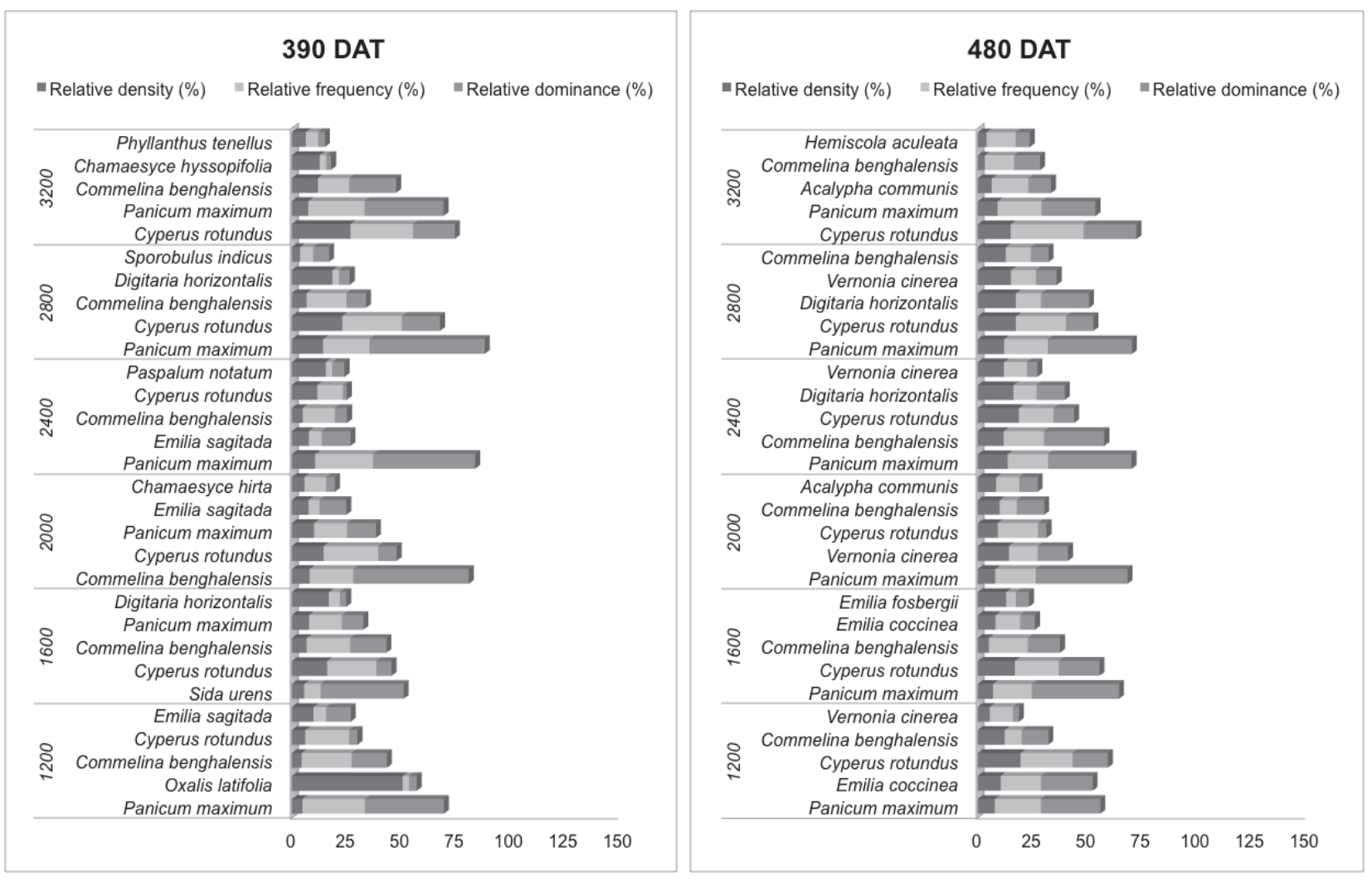

Figure 5 - Relative density (DeR), relative frequency (FrR), relative dominance (DeR) and Importance Value Index $($ IVI $=$ DeR + FrR + DeR) of the five predominant weed species at 390 and 480 DAT - Seropédica, RJ.

\section{Dominance}

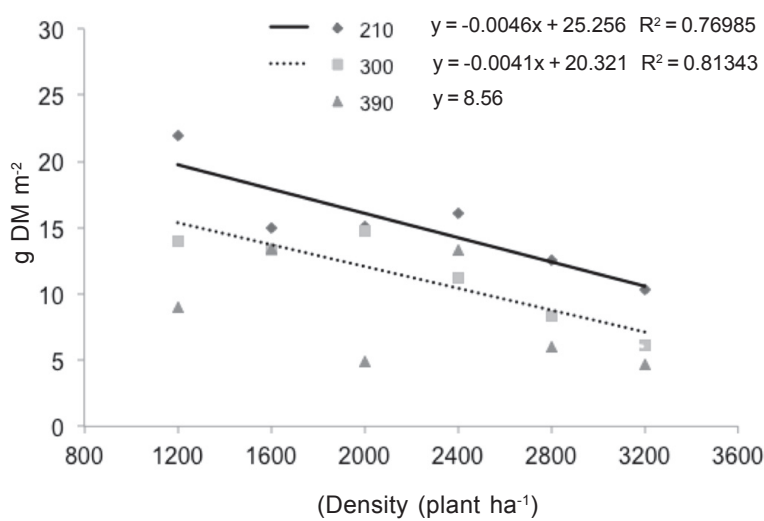

Plant Density

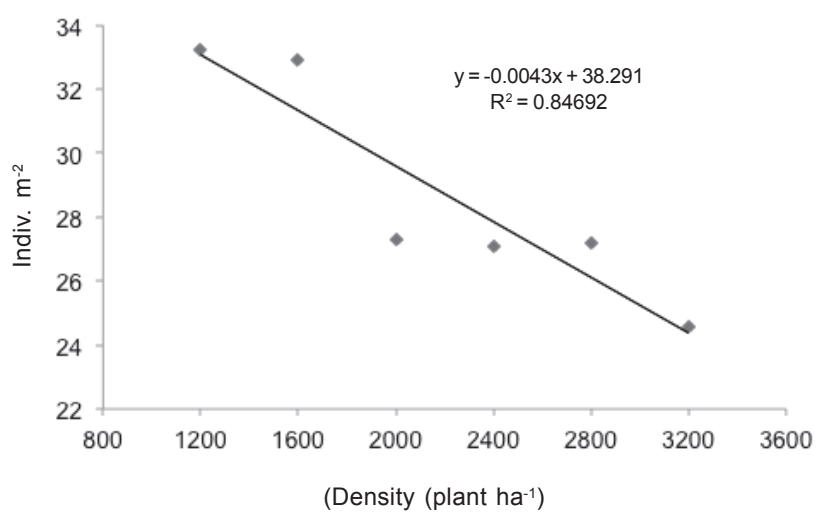

Figure 6 - Dominance $\left(\mathrm{g} \mathrm{DM} \mathrm{m}^{-2}\right.$ ) and density (Indiv. $\mathrm{m}^{-2}$ ) of weeds under the banana plants densification up to 390 DAT -

Seropédica, RJ.

Although the goal of increasing planting density is to increase crop productivity and optimize land use, this does not always result in higher yields. However, in field studies where water conditions are not limiting, it has been shown that increasing planting densities of different crops significantly reduces weed density and biomass (Nichols et al., 2015).

Comparing perennial crops such as coffee monoculture (Coffea arabica) with coffee versus banana intercropping and their effect on weed control, Concenço et al. (2014) have verified that the presence of banana in the cultivation area has significantly interfered in weed control. Ricci et al. (2004), in a study developed in the Brazilian municipality of Seropédica, RJ, in intercropped coffee plantations, have also concluded that coffee cultivation with gliricidia and banana has provided a significant reduction in weeds dry biomass. 
Usually, two factors are associated with the level of weed occurrence in cropping systems: the exudation of compounds with activities that are allelopathic to the soil and the direct effect of shading, which results in light competition, both in quantitative and qualitative aspects (Begna et al., 2002; Khan et al., 2012). Regarding the first factor, banana trees ability in commercial cultivation to produce allelopathic compounds with the power to inhibit weeds is unknown.

It was also verified in the present study that, when evaluating the number of weeds in relation to the accumulated dry matter, it is confirmed that the higher level of shading promoted by banana trees density affects not only weeds germination but also, as already described by Concenço et al. (2014), the growth capacity of these.

Weed control in crops and the advantages associated with increased crop productivity should be evaluated in comparison with the increase in seedling, seeds and production inputs costs due to the increase in crop population density (Nichols et al., 2015).

Changes were observed in the weed community during banana trees development. There was a decrease in the IVI of plants of the Poaceae family, such as $P$. maximum, to the detriment of species that are more tolerant to shading, such as C. rotundus and C. benghalensis. In addition, the densification of banana plants has favored crop control, mainly reducing weed density and dominance in the period between 210 and 300 DAT but after the harvesting beginning (390 DAT) the area returned to high IVI for the ruderal species.

Increasing crop density is a potential tool for weed control in conservationist cropping systems. The results contribute to the adoption of organic production systems or ecologically based production systems in view of the use of a banana tree genotype that, due to its recent launch, still lacks regionalized agronomic information.

Regarding banana productivity in the first production cycle, it was observed, for treatments with a lower population density of 'families' of banana trees $\left(1,200,1,600\right.$ and 2,000 plant ha' $\left.{ }^{-1}\right)$, productivities below 15 ton $\mathrm{ha}^{-1}$. On the other hand, in treatments with a higher population density $\left(2,400,2,800\right.$ and 3,200 plant ha-1), higher yields were seen, exceeding 22 ton ha ${ }^{-1}$. When adjusting productivity averages to linear regression analyses, it was observed that the correlation between these variables is highly significant, with $\mathrm{R}^{2}=0.99$ (Figure 7).

These results follow patterns of other studies involving cultivar BRS Princesa, as well as for true apples. As for productivity, they resembled or were superior to those of cultivar Maçã. By way of comparison, Lédo et al. (2008) have recorded productivity ranging from 15 to 25 ton ha-1 for

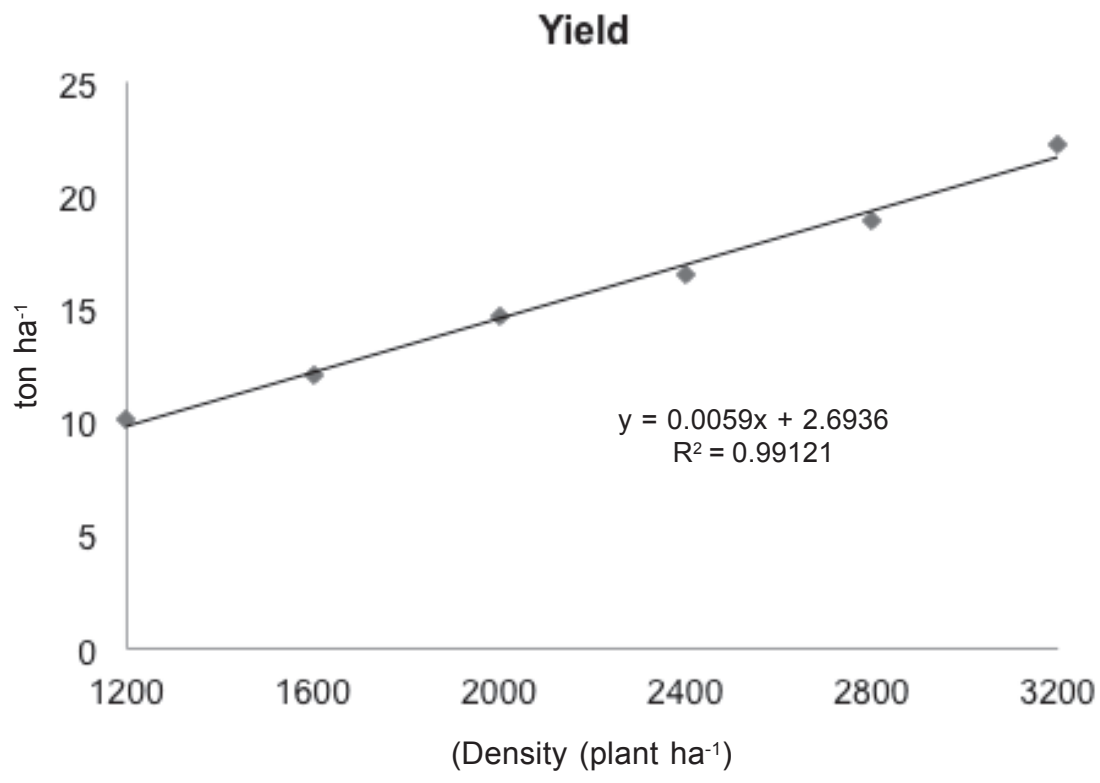

Figure 7 - Productivity of the first production cycle due to banana plants densities - UFRRJ (Universidade Federal Rural do Rio de Janeiro, Brazilian Rural Federal University of the Rio de Janeiro), Seropédica, RJ. 
this last cultivar. Likewise, several studies with irrigated silk banana have indicated an average productivity of 18 ton ha-1 (Borges et al., 2009) - lower than those found for the higher densities of the present study.

The results of the present study point out advantages in relation to crop densities, increasing banana yield per equivalent area and, consequently, optimizing land use. These benefits also add to the ability to promote the suppression of common weeds in tropical regions.

\section{ACKNOWLEDGEMENTS}

To the Fundação de Amparo à Pesquisa do Estado do Rio de Janeiro (FAPERJ) and Coordenação de Aperfeiçoamento de Pessoal de Nivel Superior (CAPES), for financial support for publishing this paper.

\section{REFERENCES}

Alves E. Plantas daninhas na cultura da banana (Musa sp.). In: Anais da $13^{\text {a }}$ Reunião Itinerante de Fitossanidade do Instituto Biológico: Cultura da Banana. Registro: Apta Regional Vale do Ribeira, 2005. p.54-60.

Begna S.H. et al. Decoupling of light intensity effects on the growth and development of C3 and C4 weed species through sucrose supplementation. J Exper Bot. 2002;53:1935-40.

Borges A.L., Souza L.S. O cultivo da bananeira. Cruz das Almas: Embrapa Mandioca e Fruticultura, 2004. 279p.

Borges A.L. et al. Sistemas de produc'aPo da bananeira irrigada. Petrolina: Embrapa Semiaìrido, 2009. (Sistemas de Produc'abo, 4).

Concenço G. et al. Infestation of weed species in monocrop coffee or intercropped with banana, under agroecological system.

Planta Daninha. 2014;32:665-74.

Costa, J.N.M. Sistema de produção para a cultura da banana no Estado de Rondônia. Embrapa Rondônia. Sistema de Produção, 2007.

FAO. Food and agriculture organization of the United Nations. [acessado em: 05 de dez. 2015]. Disponível em: http:// faostat.fao.org/

Gomes G.L.G.C. et al. Cadastramento fitossociológico de plantas daninhas na bananicultura. Planta Daninha. 2010;28:61-8.

Grichar W.J. et al. Effect of row spacing and herbicide dose on weed control and grain sorghum yield. Crop Prot. 2004;23:263-7.

Instituto Brasileiro de Geografia e Estatística - IBGE. [acessado em: 05 de dez. 2015. Disponível em: http://www.ibge.gov.br/ home/

Instituto Nacional de Metereologia - INMET. [acessado em: 05 de dez. 2015]. Disponível em: http://www.inmet.gov.br/portal/

Isaac W.P. et al. Effects of alternative weed management strategies on Commelina diffusa Burm. infestations in Fairtrade banana (Musa spp.) in St. Vincent and the Grenadines. Crop Prot. 2007;26:1219-25.

Khan N. et al. Assessment of allelopathic effects of parthenium (Parthenium hysterophorus L.) plant parts on seed germination and seedling growth of wheat (Triticum aestivum L.) cultivars. Pakistan J Weed Sci Res. 2012;18:39-50.

Lédo A.D.S. et al. Avaliação de genótipos de bananeira na região do baixo São Francisco, Sergipe. Rev Bras Frutic. 2008;30:691-5.

Lima L.K.S. et al. Distribuição fitossociológica da comunidade de plantas espontâneas na bananicultura. Rev Verde. 2012;7:59-68.

Machado A.F.L. et al. Population Dynamics of Weeds in No-Tillage and Conventional Crop Systems. J Environ Sci Health. 2005;40:119-28.

Moura Filho E.R. et al. Levantamento fitossociológico de plantas daninhas em cultivo de banana irrigada. Holos. 2015;2:92-7.

Müeller-Dombois D., Ellemberg H. Aims and methods of vegetation ecology. New York: John Wiley \& Sons, 1974.547 p. 
Nichols V. et al. Weed dynamics and conservation agriculture principles: A review. Field Crops Res. 2015;183:56-68.

Oliveira A.R., Freitas S.P. Levantamento fitossociológico de plantas daninhas em áreas de produção de cana-de-açúcar. Planta Daninha. 2008;26:33-46.

Pitelli R.A. Estudos fitossociológicos em comunidades infestantes de agrossistemas. J Conserb. 2000;1:1-7.

Pitelli R.A., Durigan J.C., Rossello R.D. Ecologia das plantas daninhas no sistema de plantio direto. In: Rossello RD. Siembra directa en el cono sur. Montevideo: PROCISUR, 2001. p.203-10.

Ricci, M.S.F. et al. Influencia do sombreamento com leguminosas arboìreas sobre a populac'abo de plantas espontaneas em aìrea cultivada com cafeeiro (Coffea canephora). Rev Agron. 2004;38:23-9. 